\title{
Multifocal PEComa (PEComatosis) of the female genital tract and pelvis: a case report and review of the literature
}

\author{
Wang Yang ${ }^{*}$, Gao Li and Zheng Wei-qiang
}

\begin{abstract}
Perivascular epithelioid cells (PECS) are constantly present in a group of tumors called PEComas, including angiomyolipoma (AML), clear-cell "sugar" tumor (CCST) of the lung and extrapulmonary sites, lymphangioleiomyomatosis, clear-cell myomelanocytic tumor of the falciform ligament/ligamentum teres and rare clear-cell tumors of other anatomic sites. PECs have distinctive morphologic, immunohistochemical, ultrastructural and genetic characteristics, including an epithelioid appearance with a clear to granular cytoplasm, a round to oval, centrally located nucleus, and an inconspicuous nucleolus. PECs also express melanocytic and myogenic markers like HMB45 and smooth muscle actin. PEComa is rare in human, and multifocal PEComas (PEComatosis) is extremely rare. Up to now there have been only less than 5 cases described in the literature. Here we report a 46year old Chinese woman who had PEComatosis arising from the genital tract and pelvis. To our knowledge, this is the first case of PEComatosis ever reported in China.
\end{abstract}

Virtual Slides: The virtual slide(s) for this article can be found here: http://www.diagnosticpathology.diagnomx.eu/ vs/1293097548652023.

Keywords: Perivascular epithelioid cell tumor (PEComa), PEComatosis, Immunohistochemistry

Perivascular epithelioid cell tumor (PEComa) refers to a family of neoplasms showing at least partial morphological or immunohistochemical evidences of a putative perivascular epithelioid cell (PEC) differentiation. PEComa may involve the visceral organs, including the lung, kidney, liver, nasal cavity, small and large bowel, appendix, prostate and uterus, and also the retroperitoneal and abdominopelvic sites. The currently reported PEComas include renal and extrarenal angiomyolipoma (AML), lymphangioleiomyomatosis (LAM), clear cell "sugar" tumor of the lung (CCST), clear cell myomelanocytic tumors (CCMMT) of the falciform ligament/ ligamentum teres and distinctive clear cell tumors at other anatomic sites. PECs have a clear or acidophilic cytoplasm and express the biomarkers of melanocytic and smooth muscle. The mean age of patients with PEComa is reportedly 45 years (ranging 40-75 years old), and there is a marked female predominance [1].

\footnotetext{
* Correspondence: docwy@sina.com

Department of Pathology, Changhai Hospital, Second Military Medical University, Shanghai 200433, China
}

(C) 2012 Yang et al; licensee BioMed Central Ltd. This is an Open Access article distributed under the terms of the Creative Commons Attribution License (http://creativecommons.org/licenses/by/2.0), which permits unrestricted use, distribution, and reproduction in any medium, provided the original work is properly cited.
Here we describe a 46-year-old Chinese woman who had multifocal perivascular epithelioid cell tumor (PEComatosis) arising from the genital tract and pelvis.

\section{Case report}

In Nov, 2010, a 46-year-old woman was referred to Department of Ggyneco-obstetrics of Changhai Hospital due to a uterus mass and a left pelvic adnexal mass, which were palpated during a routine physical examination, but presenting no abnormal vaginal bleeding and stigmata of the tuberous sclerosus complex. Serum CA125 and CA-19-9 levels as well as other laboratory findings were all within the normal limits. Transabdominal sonography revealed a uterus mass (diameter $3.2 \mathrm{~cm}$ ), a left pelvic adnexal cystic mass (diameter $3.7 \mathrm{~cm}$ ) and a left pelvic mass(diameter $4.9 \mathrm{~cm}$ ). The initial clinical impression of the lesions was uterus leiomyoma and left ovary chocolate cyst. Then the patient underwent a total abdominal hysterectomy and bilateral salpingo-oophorectomy. Intraoperative findings included smooth surface masses arising from the posterior wall of the enlarged
C Biomed Central 
uterus (diameter $3 \mathrm{~cm}$ ), right part of cervix (diameter 3 $\mathrm{cm}$ ) and the left broad ligament (diameter $4 \mathrm{~cm}$ ), with hypertrophic ovaries, normal fallopian tubes, without ascites. An intraoperative frozen section of the uterine mass was interpreted as leiomyoma.

The surgical specimens were collected and fixed in $10 \%$ formalin for H-Estaining and immunohistochemical staining. The immunophenotypes of tumor cells was examined by EnVision Plus system (DAKO Corporation). The antibodies used included HMB-45 (1:50), Melan-A(1:50), smooth muscle actin (1:50), calponin (1:100), CD34 (1:50), CD10(1:100), S-100(1:200), p53 (1:50), estrogen receptor $(1: 80)$, progesterone receptor (1:40) and MIB-1 (1:200). The surgical specimens included a $9 \mathrm{~cm} \times 6 \mathrm{~cm} \times 6 \mathrm{~cm}$ uterus with left adnexae and right cavitas pelvis masses. Grossly, two round masses were found in the uterine, with a $3 \mathrm{~cm} \times 3 \mathrm{~cm} \times$ $2 \mathrm{~cm}$ mass in the myometrium and a $3 \mathrm{~cm} \times 3 \mathrm{~cm} \times 3$ $\mathrm{cm}$ mass in the subserosa of posterior wall; a mass measuring $5 \mathrm{~cm} \times 5 \mathrm{~cm} \times 4 \mathrm{~cm}$ was found in the left broad ligament, multiple masses were found in the right cavitas pelvis, with the largest diameter being $3 \mathrm{~cm}$ (Figure $1)$. The masses were round or nodulose, solid, welldemarcated and partially encapsulated by thin membranous tissue. The cross section surfaces of the masses were grayish-white, without fresh, old hemorrhage or necrosis. A $3 \mathrm{~cm} \times 3 \mathrm{~cm} \times 3 \mathrm{~cm}$ cystic tumor was found on the left adnexa. H-E staining showed that all the PEC lesions in our case had a similar morphological feature under microscope. The tumors were mainly composed of epithelioid cells, with a few spindle-shaped cells; the tumor cells had abundant clear-to-fine eosinophilic granular cytoplasm, with round to oval nuclei, mild-to-moderate pleomorphism and a mitotic count of 1-4/50HPF. There were no necroses; the tumor cells were arranged in nests, bundles or patches; some surrounded and radiated alone the blood vessels. And there were no pathological mitoses. Proliferation of thinwalled capillary-like vessels was also noted in foci with occasional glomerulus-like vascular tuft formation. There were no mature adipose tissues, spindle-shaped smooth-muscle bundles, or abnormal thick-walled blood vessels characteristic of classic AML and necrosis. Immunohistochemically, the tumor cells were negative for CD34, CD10, S-100 and p53, and strongly positive for HMB-45 (Figure 2C) and Melan-A, smooth muscle actin (SMA), calponin (Figure 2D), ER and PR. A low proliferative fraction was detected with MIB-1 antibody (3-5\% positive MIB-1 staining). PAS staining without diastase predigestion found that some tumor cells were positive, and PAS staining with diastase predigestion showed completely negative results. Masson staining of the connective tissues showed a great deal of collagen fibers in the stroma.

Other specimens revealed chronic cervicitis, endometrium of proliferative phase, follicular cyst of left ovary,

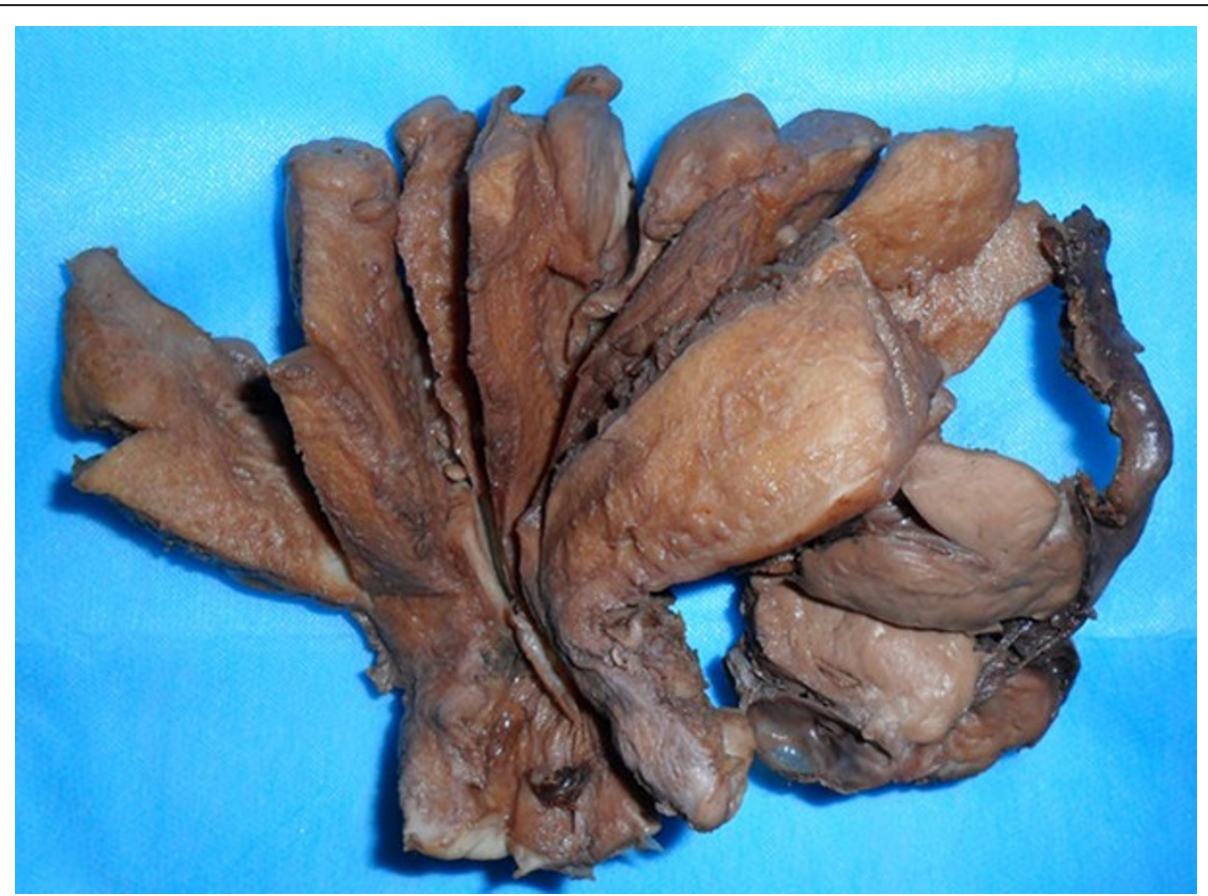

Figure 1 The uterus had 2 myometrial nodules(arrows) and the left broad ligament had a lobulated nodule (star). No hemorrhage, necrosis or infiltrative features were seen in the uterine corpus, ovary, or fallopian tube. 

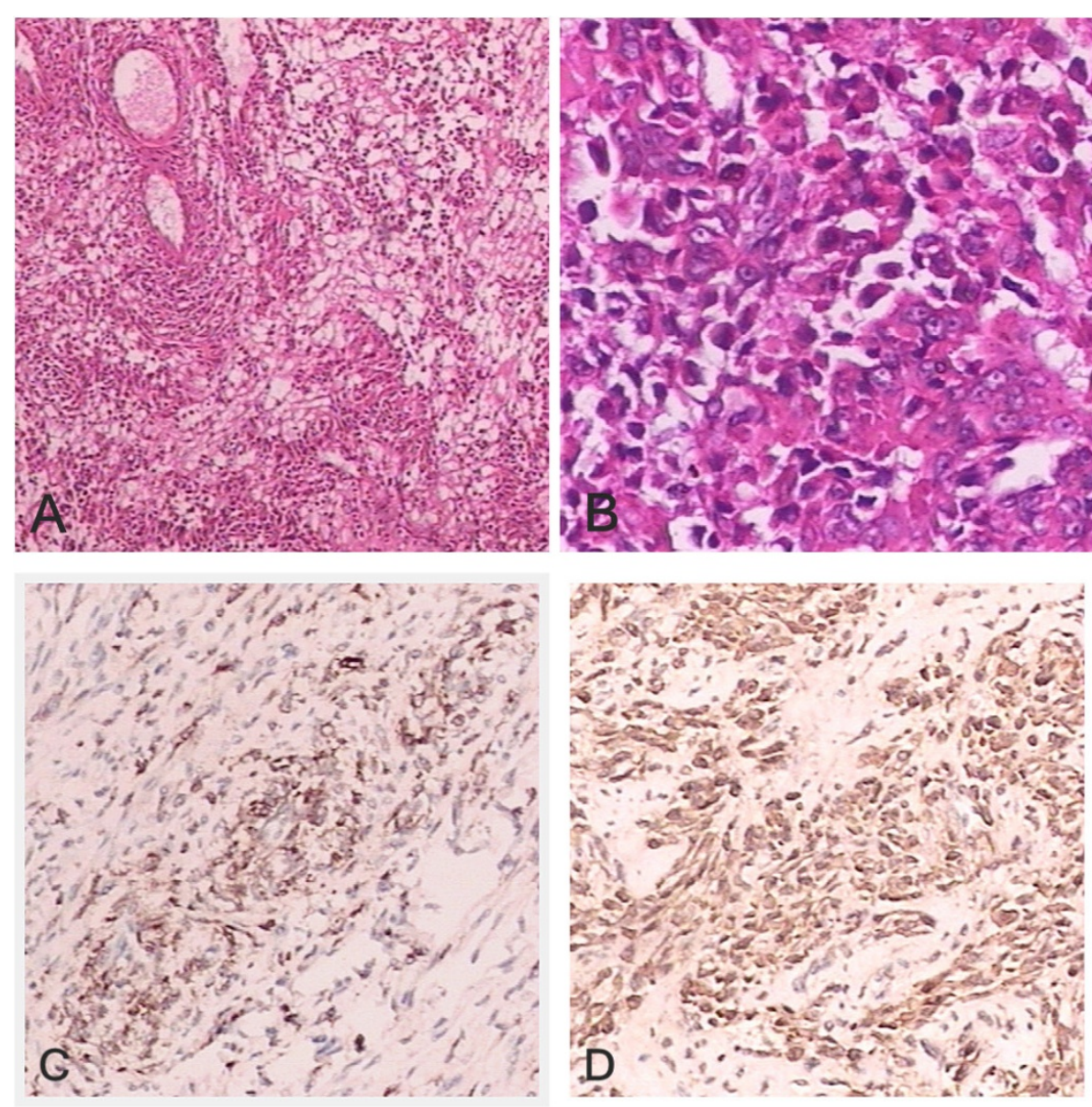

Figure 2 (A) Epithelioid tumor cells are around the delicate vasculature (perivascular arrangement; $\mathrm{H}-\mathrm{E}, \times \mathbf{4 0}$ ). (B) Perivascular epithelioid cells are round to polygonal with abundant clear to finely eosinophilic granular cytoplasm and round nuclei $\left(H-E_{1} \times 200\right)$. The epithelioid cells are immunoreactive for HMB-45(C) and calponin(D), with the characteristic "myomelanocytic" immunophenotype of PEComas.

normal right ovary, and fallopian tubes. The postoperative course was uneventful, and the patient was discharged 4 days after surgery. No further treatment was needed; and no recurrence was noticed 12 months later as shown by transabdominal sonography of the abdomen and pelvis. She is currently followed up regularly by ultrasonography.

\section{Discussion}

PECs, first described by Bonetti et al [2], do not have a normal anatomic homologue. PECs are characterized by co-expression of melanocytic and muscle markers, epithelioid to spindle shapes with ample clear to eosinophilic cytoplasm, and at least in some cases, arrangement around blood vessels [3]. The term "PEComa"(perivascular epithelioid cell tumor) was introduced in 1996 by Zamboni et al [4], as synonym for tumors composed primarily by PECs. In the WHO soft tissue volume, PEComas are defined as "mesenchymal tumors composed of histologically and immunohistochemically distinctive perivascular epithelioid cells" [5], including entities such as AML, LAM, and CCST of the lung. In recent years, more tumors are being reported and categorized as members of the PEComa family, including monotypic epithelioid AML, extrapulmonary CCST, and clear-cell myomelanocytic tumor (CCMMT) of the falciform ligament/ligamentum teres.

PEComas may arise from multiple anatomical sites, including the kidney, lung, pancreas, liver, uterus, breast, ligament teres, falciform ligament, orbit, skin and soft tissue, with the uterus and retroperitoneum appearing to be the most frequent sites of origin. The first case of uterus PEC tumor was reported by Pea et al [6]. PEComas share a common morphophenotypic feature: diffuse, nested and/or fascicular proliferation of spindled and epithelioid cells, tumor cells with clear to eosinophilic cytoplasm, centrally located nuclei, and immunoreactivities to both the melanogenic-related markers and to a lesser extent, muscular markers. Folpe et al [7] reported CD117 reactivity in about $5 \%$ of PEComas. Ultrastructurally, 
structures interpreted as melanosomes and premelanosomes have been demonstrated in PEComa of the uterus [8]. Vang and Kempson [9] divided uterine PEComas into $\mathrm{A}$ and $\mathrm{B}$ types. Type $\mathrm{A}$ tumors show a tongue-like growth pattern and are composed of cells with clear to eosinophilic pale granular cytoplasm, diffuse HMB- 45 expression, and focal smooth muscle reactivity. Type $B$ tumors are composed of epithelioid cells with less prominent clear cell features, with only a few of being HMB- 45 positive; in addition, cells of type $\mathrm{B}$ tumor demonstrate an extensive muscle marker expression and a lesser degree of tongue-like growth pattern.

Uterine PEComa lacks characteristic clinical and imaging changes; the diagnosis mainly relies on pathological approach, and should be differentiated from the following tumors: (1) Epithelioid smooth muscle tumor (ESMT)- the ESMT cells are round, polygonal and spindle-shaped; the spindle-shaped cells had cigarette-like nuclei with rounded ends; there was typical smooth muscle transition; they are usually HMB45 negative, without characteristic capillarity network of bloodvessels. PEComa is supplied by rich blood vessels, and the tumor cells surrounded the blood vessels, forming into patches and nests; they are often HMB45 positive. It has also been reported that a small number of ESMT cells could be HMB45 positive, but Melan-A negative; therefore double positive for SMA and Melan-A indicate a higher probability of PEComa. (2) Endometrial stromal sarcoma(ESS)-the tumor cells are spindle-shaped with less cytoplasm and negative for HMB45; PEComa cells are large and round or polygonal in shape, with rich eosinophilc cytoplasm, and are HMB45 positive. Some PEComa patients also have lymphangioleiomyomatosis and tuberous sclerosis, which has not reported in ESS patients. (3) Uterine clear cell carcinoma (UCC)-the tumor is composed of cells with clear cytoplasm and a hobnail morphology, which forming into solid, ductal or papillary shapes, negative for $\mathrm{HMB} 45$ and positive for CK. (4) Metastatic renal clear cell carcinoma (MRCcc)the cytoplasm is clear and polygonal shaped; the round tumor cells arranged into nest, alveolar, ductal, or papillary shapes, but with no perivessel structure; the tumor is HMB45 negative, and CK, EMA positive. (5) Paraganglioma-it should be differentiated with PEComa when the cytoplasm is clear. Paraganglioma cells are arranged in streaks, glands, or nests, with flat supporting cells lining around, and with distinct organoid and pseudorosette structure; besides, they are HMB45 negative, and NSE, Syn, CgA and NF positive; the supporting cells are positive for S-100 protein.

PEComas have been reported as predominantly benign. Greene [10] believed that uterine PEComas were tumors with uncertain malignant potentials. Folpe et al [7] reported PEComas in 26 patients with soft tissue and gynaecologic origin, and classified the tumors as "benign", "of uncertain malignant potential" and "malignant"; they also observed a significant association between tumor size $>5 \mathrm{~cm}$, infiltrative growth pattern, high nuclear grade, necrosis and mitotic activity $>1 / 50 \mathrm{HPF}$ with aggressive behavior of PEComas. The 2002 WHO soft tissue and bone book [5] states that PEComas have the following features: infiltrative growth, marked hypercellularity, nuclear enlargement, hyperchromasia, high mitotic activity, atypical mitotic figures, and coagulative necrosis, and therefore PEComas should be regarded as malignant. However, by now we have failed to understand the real behavior of these ubiquitous tumors, because some tumors with "benign" appearance have aggressive behavior and others with "malignant" appearance have indolent course. Late recurrences of the tumor have been reported, including one with lung metastasis 7 years after the primary tumor had been described [11].

Table 1 Reported Cases of PEComatosis in the English Language Literature (5 Cases)

\begin{tabular}{|c|c|c|c|c|c|}
\hline Reference & $\begin{array}{c}\text { Age/ } \\
\text { Sex }\end{array}$ & Site/Maximum Size (cm) & Histopathology & Immunohistochemistry & Comments \\
\hline $\begin{array}{l}\text { Fadare } \\
2004[12]\end{array}$ & $41 / F$ & $\begin{array}{l}\text { Myometrium, small } \\
\text { bowel lamina propria, } \\
\text { ovarian hila/2.2 }\end{array}$ & $\begin{array}{c}\text { No cytological atypia, mitotic activity or } \\
\text { necrosis. }\end{array}$ & HMB-45 positive & $\begin{array}{l}\text { With TSC. No recurrence } \\
\text { or metastases at } 35 \\
\text { months' follow-up. }\end{array}$ \\
\hline $\begin{array}{l}\text { Salviato } \\
2006[13]\end{array}$ & $70 / F$ & Diffuse peritoneum/6 & $\begin{array}{c}\text { Epithelioid and spindle cells, mild to } \\
\text { moderate nuclear pleomorphism, focal areas } \\
\text { of necrosis. }\end{array}$ & $\begin{array}{l}\text { HMB45, melan-A, and SMA } \\
\text { positive, desmin and S100 } \\
\text { negative. }\end{array}$ & $\begin{array}{l}\text { With a history of ancient } \\
\text { hysterectomy for fibroids }\end{array}$ \\
\hline $\begin{array}{l}\text { Liang } \\
2008[14]\end{array}$ & $59 / F$ & $\begin{array}{c}\text { Pelvic lymph nodes, } \\
\text { myometrium, cervix, and } \\
\text { ovary } / 2.6\end{array}$ & $\begin{array}{c}\text { Marked nuclear pleomorphism, necrosis, } 2 \\
\text { mitoses/50 HPF, occasional atypical mitosis, } \\
\text { infiltrative borders. }\end{array}$ & $\begin{array}{l}\text { HMB45, melan-A, SMA and } \\
\text { ER positive. }\end{array}$ & With TSC. \\
\hline $\begin{array}{l}\text { Froio } 2008 \\
\quad[15]\end{array}$ & $39 / F$ & $\begin{array}{l}\text { Uterine corpus, both } \\
\text { ovaries, and the } \\
\text { omentum/ }\end{array}$ & & $\begin{array}{l}\text { HMB45, melan-A, SMA, ER } \\
\text { and PR positive. }\end{array}$ & With TSC. \\
\hline $\operatorname{Lim}_{[16]} 2011$ & $59 / F$ & $\begin{array}{l}\text { Uterine, cervix, uterine } \\
\text { corpus. }\end{array}$ & $\begin{array}{l}\text { Mature adipose tissue, spindle cells, small } \\
\text { nests of clear epithelioid cells }\end{array}$ & & With TSC. \\
\hline
\end{tabular}


Due to the multicentricity of the lesions, we favor the designation of PEComatosis proposed by Fadare et al [12]. PEComatosis is very rare. Table 1 summarizes the clinical properties of all the five PEComatosis cases reported in the English literature. All the 5 cases were women aged 39-70 years old (a mean of 54 years old). Most cases involved the uterus, cervix and the genital system, and were complicated with TSC. Our case was a 46 years old woman involving the uterus, cervix, broad ligament and pelvic cavity, but without evidence of TSC.

Whether the multiple foci of PEComas are truly multicentric or whether they originate from a single primary site remains to be further investigated. To the best of our knowledge, the present case is the first PEComatosis in China. Treatment of PEComas is challenging since chemotherapy and radiotherapy seem not effective, and surgery is currently the most important treatment of these tumors.

\section{Acknowledgements}

YU Dang-hui

\section{Authors' contributions}

WY first identified this case,retrieved clinical information and wrote the manuscript. GL and ZW-q proposed the studies and provided valuable insight during manuscript preparation. All authors read and approved the final manuscript.

\section{Competing interests}

The authors declare that they have no competing interests.

Received: 7 January 2012 Accepted: 9 March 2012

Published: 9 March 2012

\section{References}

1. Tavassoli FA, Devilee P: World Health Organization classification of tumors. Pathology and genetics of tumors of the breast and the female genital organs Lyon: IARC Press; 2003, 243-244.

2. Bonetti F, Pea M, Martignoni G, et al: Clear cell ("sugar") tumor of the lung is a lesion strictly related to angiomyolipoma-the concept of a family of lesions characterized by the presence of the perivascular epithelioid cells (PEC). Pathology 1994, 26:230-236.

3. Bonetti F, Pea M, Martignoni G, et al: The perivascular epithelioid cell and related lesions. Adv Anat Pathol 1997, 4:343-358.

4. Zamboni G, Pea M, Martignoni G, et al: Clear cell 'sugar' tumor of the pancreas: a novel member of the family of lesions characterized by the presence of perivascular epithelioid cells. Am J Surg Pathol 1996, 20:722-730.

5. Folpe AL: In World Health Organization Classification of Tumors. Pathology and genetics of tumors of soft tissue and bone. Edited by: Fletcher CDM, Unni KK, Mertens F. Lyon: IARC Press; 2002:221-222, Neoplasms with perivascular epithelioid cell differentiation (PEComas).

6. Pea M, Martignoni G, Zamboni G: Perivascular epithelioid cell. Am J Surg Pathol 1996, 20:1149-1153.

7. Folpe AL, Mentzel T, Lehr HA, et al: Perivascular epithelioid cell neoplasms of soft tissue and gynecologic origin: a clinicopathologic study of 26 cases and review of the literature. Am J Surg Pathol 2005, 29:1558-1575.

8. Park SH, Ro JY, Kim HS, et al: Perivascular epithelioid cell tumor of the uterus: immunohistochemical, ultrastructural and molecular study. Pathol Int 2003, 53:800-805.

9. Vang R, Kempson RL: Perivascular epithelioid cell tumor ("PEComa") of the uterus: a subset of HMB-45-positive epithelioid mesenchimal neoplasms with an uncertain relationship to pure smooth muscle tumors. Am J Surg Pathol 2002, 26:1-13.
10. Greene LA, Mount SL, Schned AR, et al: Recurrent perivascular epithelioid cell tumor of the uterus (PEComa):an immunohistochemical study and review of the literature. Gynecol Oncol 2003, 90:677-681.

11. Dimmler A, Seitz G, Hohenberger W, et al: Late pulmonary metastasis in uterine PEComa. J Clin Pathol 2003, 56:627-628.

12. Fadare $O$, Parkash $V$, Yilmaz $Y$, et al: Perivascular epithelioid cell tumor (PEComa) of the uterine cervix associated with intrabdominal "PEComatosis": a clinicopathologic study with comparative genomic hybridizaton analysis. World J Surg Oncol 2004, 2:35

13. Salviato $T$, Altavilla $G$, Busatto $G$, et al: Diffuse intra-abdominal clear cell myomelanocytic tumor: report of an unusual presentation of "PEComatosis" simulating peritoneal mesothelioma. Ann Diagn Pathol 2006, 10:352-356.

14. Liang SX, Pearl M, Liu J, et al: "Malignant" uterine perivascular epithelioid cell tumor, pelvic lymph node lymphangioleiomyomatosis, and gynecological pecomatosis in a patient with tuberous sclerosis: a case report and review of the literature. Int J Gynecol Pathol 2008, 27:86-90.

15. Froio E, Piana S, Cavazza A, et al: Multifocal PEComa (PEComatosis) of the female genital tract associated with endometriosis, diffuse adenomyosis, and endometrial atypical hyperplasia. Int J Surg Pathol 2008, 16:443-446.

16. Lim GS, Oliva E: The morphologic spectrum of uterine PEC-cell associated tumors in a patient with tuberous sclerosis. Int J Gynecol Pathol 2011, 30:121-128.

doi:10.1186/1746-1596-7-23

Cite this article as: Yang et al:: Multifocal PEComa (PEComatosis) of the female genital tract and pelvis: a case report and review of the literature. Diagnostic Pathology 2012 7:23.

\section{Submit your next manuscript to BioMed Central and take full advantage of:}

- Convenient online submission

- Thorough peer review

- No space constraints or color figure charges

- Immediate publication on acceptance

- Inclusion in PubMed, CAS, Scopus and Google Scholar

- Research which is freely available for redistribution 